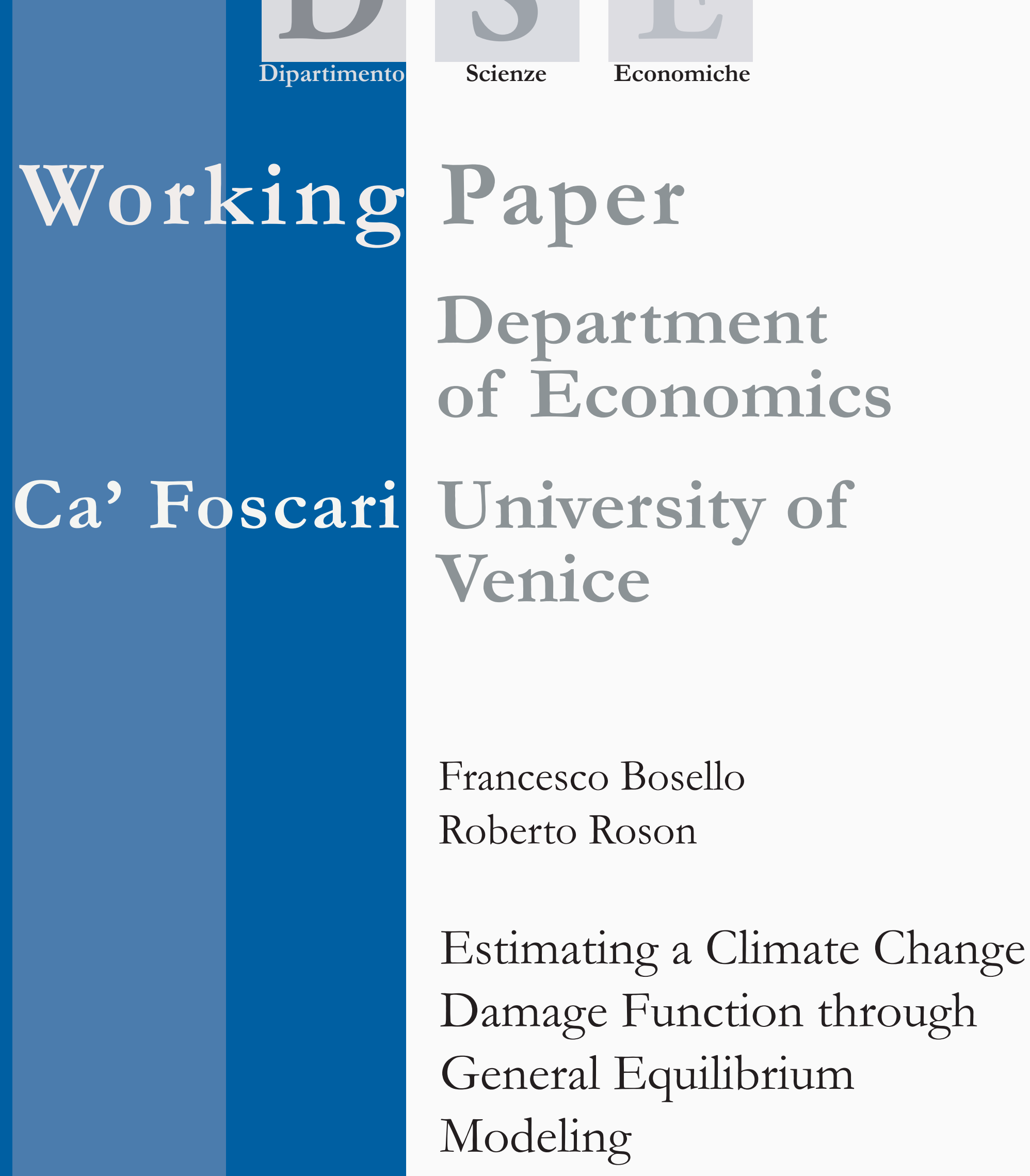


Working Papers

Department of Economics

Ca' Foscari University of Venice

No. $08 / \mathrm{WP} / 2007$

ISSN $1827-3580$

\title{
Estimating a Climate Change Damage Function through General Equilibrium Modeling
}

\author{
Francesco Bosello \\ Università di Milano
}

Roberto Roson

Università Ca'Foscari di Venezia

First Draft: July 2007

\begin{abstract}
A Climate Change Damage Function (CCDF) is a reduced form relationship linking macroeconomic aggregates (e.g., potential GDP) to climate indicators (e.g., average temperature levels). This function is used in a variety of studies about climate change impacts and policy analysis. However, despite the fact that this function is key in determining results in many integrated assessment models, it is not typically calibrated in a consistent and rigorous way.

This paper presents a novel approach, in which several different impacts of climate change are first assessed by means of a full-fledged computable general equilibrium model of the world economy, then results are interpolated to get a simple relationship of the CCDF type. The estimated CCDF is compared with other popular functions used in the literature, to highlight the possible implications associated with the alternative adoption of this functional relationship.
\end{abstract}

\section{Keywords}

Climate Change, Damage Function, Integrated Assessment, General Equilibrium

\section{JEL Codes}

C68, D58, F18, Q51, Q54

Address for correspondence: Roberto Roson

Department of Economics Ca' Foscari University of Venice Cannaregio 873, Fondamenta S.Giobbe 30121 Venezia - Italy Phone: (++39) 041234

Fax: $(++39) 0412349176$ e-mail: roson@unive.it

This Working Paper is published under the auspices of the Department of Economics of the Ca' Foscari University of Venice. Opinions expressed herein are those of the authors and not those of the Department. The Working Paper series is designed to divulge preliminary or incomplete work, circulated to favour discussion and comments. Citation of this paper should consider its provisional character.

The Working Paper Series
is availble only on line
(www.dse.unive.it/pubblicazioni)
For editorial correspondence, please contact:
wp.dse@ $@$ unive.it

Department of Economics

Ca' Foscari University of Venice

Cannaregio 873, Fondamenta San Giobbe

30121 Venice Italy

Fax: ++390412349210 


\section{Introduction}

Environmental Integrated Assessment involves integration of natural/environmental models with social/economic models. For example, climate change models are based on scenarios of economic growth, which are necessary to estimate emissions and concentrations of greenhouse gases in the future. Information about GHG concentrations is fed into climate models, to generate forecasts of temperature levels and other climate variables, eventually associated to physical impacts on: agricultural productivity, coastal erosion, water availability, etc.

Global Circulation Models (GCM) are typically used to estimate future scenarios of climate change. Since GCMs can be very complex and computationally demanding, it is practically impossible to hard-link a full GCM with socio-economic models into an Integrated Assessment Model (IAM). The typical solution is then the introduction of a reduced form model, consisting only of a few equations. Analogously, a similar approach is often adopted for the economic side. Most models adopt a Climate Change Damage Function, which is a simple relationship linking climate indicators (e.g., average temperature) to variables of economic performance (e.g., per capita income, GDP, etc.).

The main problem with CCDFs is their lack of derivation from large-scale, internally consistent, macroeconomic models. The damage function is not usually based on a distinction among various impacts that the changing climate may have on the economy. Trade linkages between industries and regions, which are essential to understand how shocks propagate into the economic system, are poorly represented, or altogether absent. Damages are normally computed by multiplying physical damages by some constant prices, disregarding the issue of price endogeneity, and forgetting about the intrinsic adaptive capacity of all economic systems.

On the other hand, it is clear that results of IAM models are highly sensitive to assumptions about climate change damages. Using different CCDFs, different results may be obtained in terms of: environmental policies, international negotiations, and consequences on natural and human systems. In this paper we advocate, for the economic side of IAM models, an approach similar to the one of climate models: simple relationships should be derived from large-scale, full-fledged, macroeconomic models. We propose using a world-scale Computable General Equilibrium model to this purpose. As an illustration, we show some preliminary results obtained with a model, derived from the GTAP model and data set, which has been used as a common framework, to encompass a variety of climate impacts. The model structure, as well as the results obtained for various sectors, 
are described in detail in a set of papers assessing single impacts, e,g.: Berritella et al., Bosello et al. (2006), Bosello et al., (2007), Bosello and Zhang (2006).

In this study, we consider all the different impacts together and, instead of assuming a specific climate change scenario, we experiment with various temperature levels, to get a series of "points" along a hypothetical function, linking temperature to macroeconomic variables, like GDP. A manageable functional form is subsequently obtained through interpolation.

We compare this function with some other functions adopted in the IAM literature. As an illustration, a detailed comparison is made with the CCDF used in the popular RICE 99 model.

The rest of the paper is organized as follows. The next section provides an overview of some climate change damage functions proposed in the literature. Section 3 illustrates the basic characteristics of the CGE model, and explains how simulation exercises have been realized. Section 4 presents our estimates of the CCDF. Section 5 compares our CCDF with the one used in the RICE 99 model. A final section draws some conclusions.

\section{Climate Change Damage Functions: a brief overview}

Different functional forms for CCDF, and alternative approaches for their parametrisation, can be found in the literature. Without aiming to be exhaustive, we briefly describe the methodology adopted in a few popular models: the Nordhaus and Yang RICE 96 model (1996), the Nordhaus and Boyer RICE 99 (1999a,b) model, the Manne and Richels MERGE model (1992, 1995, 1999, 2004b), the Peck and Teisberg CETA model (1992, 1993, 1994) and Tol's FUND model (1996, 1997, 1999, 2005). All these studies are mentioned in various IPCC reports (see e.g. Pearce et al. (1996), Schneider et. al (2001)).

Table 1 presents the climate change damage functions used in some of these models, relating average temperature $(T)$ at time $t$ to shares of potential GDP $(C C D)$.

A quick inspection of Table 1 reveals some striking methodological differences. The damage is a linear function of average temperatures in MERGE, but the relationship is non-linear in all other cases. Whereas the function is asymptotic in the RICE models (reaching, in the limit, $100 \%$ of the GDP), the function is uniformously convex in CETA. Further differences arise in terms of parameters estimation. The methodologies are summarized in the following.

\section{$\underline{\text { RICE } 96}$}


In RICE 96, climate change impacts are calculated for a global mean temperature increase of $3^{\circ} \mathrm{C}$, for all regions in the model and for a number of "impact areas": agriculture, energy, sea-level rise and "other sectors". Results, especially for developing regions, are largely based on extrapolation of US data, with ad hoc assumptions. Impacts are summed across impact categories to determine the total loss as a percentage of GDP, for each region. Estimated losses range from $0.72 \%$ of GDP, for landlocked states with little agriculture, to more than $4 \%$ of GDP, for countries with many coasts and a large agricultural sector. The pair $\left(3^{\circ} \mathrm{C}\right.$ temperature variation, estimated GDP loss) allows the calibration of the first theta parameter in the CCDF relationship, whereas the second parameter is set to $2 .^{1}$

\section{$\underline{\text { RICE } 99}$}

In RICE 99 the calibration of the CCDF is similar to that of RICE 96, but slightly more sophisticated and richer in data. Climate change impacts are estimated using two reference temperature increases, $2.5^{\circ} \mathrm{C}$ and $6^{\circ} \mathrm{C}$, and more "impact categories": agriculture, sea-level rise, other market sectors, health, non-market amenity, human settlements and ecosystem, catastrophic events. Impacts are projected to 2100 assuming an income adjustment factor. A system of two quadratic equations is solved for each region, to estimate the damage coefficients.

\section{MERGE}

In the MERGE model, market and non-market damages of climate change are considered. For market damages, parameters are calibrated by assuming that a $2.5^{\circ} \mathrm{C}$ temperature rise would lead to GDP losses of $0.25 \%$ in high income countries and $0.50 \%$ in low income countries. Nonmarket damages include impacts on human health, losses of species and deterioration of environmental quality. This second function is calibrated on the assumption that, to avoid a $2.5^{\circ} \mathrm{C}$ temperature rise, developed countries would be willing to give up $2 \%$ of their potential GDP (which is about the current U.S. total expenditure on environmental protection).

\section{CETA}

The CCDF of the CETA model is quite similar to that of the RICE 96 model. This CCDF is calibrated by associating a temperature increase of $3^{\circ} \mathrm{C}$ with a $0.2 \%$ loss in the world GDP. Furthermore, some theta parameters are time variant, increasing at an exogenous rate.

\section{$\underline{\text { FUND }}$}

Damages in the FUND model are estimated in a rather different way. Climate change costs for each impact category (agriculture, forestry, water, energy consumption, sea-level rise, ecosystems, 
Table 1: Different Climate Change Damage Functions

\begin{tabular}{|c|c|}
\hline RICE 96 & $C C D_{i}(t)=1-\frac{1}{1+\theta_{1, i}(T(t) / 3)^{\theta_{2}}}$ \\
\hline RICE 99 & $C C D_{i}(t)=1-\frac{1}{1+\theta_{1, i} T(t)+\theta_{2, i} T(t)^{2}}$ \\
\hline MERGE & $M C C D_{i}(t)=\theta_{1, i} \frac{T(t)-T_{t=2000}}{2.5}$ \\
CETA & $N M C C D_{i}(t)=\frac{T(t)-T_{t=2000}}{17.7}$ \\
\hline
\end{tabular}

vector-borne and heath/cold-stress related diseases) are calculated "dynamically". This is because distinct CCDFs are estimated for each impact category.

\section{Methodology, model characteristics and simulation exercises}

The Computable General Equilibrium model used in this paper is based on a series of variants of the GTAP-E model (Burniaux and Truong, 2002). The basic structure of the model is described in Hertel (1996).

This model has been used to assess the economic impact of climate change in several dimensions, using a comparative static approach. First, a baseline benchmark is built, by changing exogenous variables and parameters, following Dixon and Rimmer (2002). In essence, this amounts to estimate the hypothetical structure of the world economy at one selected year (here, 2050), in the absence of climate change or other macroeconomic shocks, through changes in the national endowments of labour, capital, land, natural resources, as well as variations in factor-specific and multi-factor productivity.

This benchmark is subsequently compared with some counter-factual scenarios, in which a number of effects of climate change are simulated. Physical impacts of climate change are interpreted as exogenous variations of economic variables and parameters. This may involve changes in endowments of primary resources, and/or changes in productivity, technology, consumption 
patterns, saving propensity. These exogenous shocks induce a structural adjustment in the economy, bringing about a new equilibrium state for all interrelated markets.

We list here below the climate change impacts considered in this study, briefly describing how the various impact have been simulated in the model. For more information, the interested reader may refer to the cited papers, specifically devoted to the different impact analyses.

\subsection{Sea Level Rise}

The coastal land loss deriving from different scenarios of sea level rise, assuming no coastal protection, has been estimated worldwide at the country level. Land lost has been calculated by elaborating results from the Global Vulnerability Assessment (Hoozemans et al., 1993), integrated with data from Bijlsma et al. (1996), Nicholls and Leatherman (1995), Nicholls et al. (1995) and Beniston et al. (1998). The methodology and some results are illustrated in Bosello et al. (2006).

Simulations in the CGE model have been produced by exogenously reducing the amount of the primary factor "land" in all regions (see Table A1).

\section{$\underline{3.2 \text { Tourism }}$}

The impacts of climate change on tourism are based on the Hamburg Tourism Model (HTM), version 1.2 (Bigano et al., 2005). This is an econometric simulation model, estimating the number of tourists by country, the share of international tourists in total tourists, and tourism flows between countries. These are determined by climatic and "environmental" components (temperature and coastal length) and by socio-economic factors (population, prices and income). HTM offers also data on tourists' (per capita, daily) expenditure.

Changes in tourism flows are accommodated in the CGE model in two ways. First, a shifting factor induces exogenous variations in the households' demand for domestic market services, at constant prices and income. The exogenous change amounts to the estimated variation in expenditure by tourists. Secondly, national incomes are adjusted, to account for the purchasing power of foreign tourists. Data on tourism demand and income flows are reported in Table A2, in the Appendix.

\section{$\underline{3.3 \text { Energy demand }}$}

Variations of energy demand as a consequence of rising temperatures have been calculated, using elasticities from Bigano et al., (2006). The latter study investigates the effect of temperature on demand for different energy vectors. Estimated changes in households' demand for energy commodities, for various temperature levels, are presented in Table A3. Variations in energy demand are modelled through exogenous shifts in the households' demand, like in the case of tourism. 


\section{$\underline{3.4 \text { Agriculture }}$}

Climate change impacts on agriculture are based on Tol (2002) who extrapolated changes in yields for a given scenario of climate change. In the CGE model, changes in yields are modelled through exogenous changes in the productivity of land, devoted to different crops. Changes in land productivity are reported in the Appendix, Table A4.

\section{$\underline{3.5 \text { Health }}$}

Two main drivers of economic impacts from climate change are considered: variation of working hours, responding to changes in mortality and morbidity; variation in the expenditure for health care services, undertaken by public administrations and private households.

These effects, related to six classes of climate related diseases (malaria, dengue, schistosomiasis, diarrhoea, cardiovascular and respiratory) have been computed for the 17 regions of the CGE model (see Bosello et al. (2006)). Parameters used in the health simulations are summarized in Tables A5 and A6.

\section{Estimating a Climate Change Damage Function}

When all the different shocks are implemented simultaneously in the CGE model, a counter-factual equilibrium for the world economy is estimated. By varying the reference temperature levels, the model produces sets of macroeconomic variables.

For example, Figure 1 plots the relationships between temperatures and percentage variations in real GDP, with respect to the benchmark, for the 15 regions of the model. ${ }^{2}$

\footnotetext{
${ }^{2}$ For the meaning of the regions' acronyms, see Table 1.
} 
Figure 1: Climate change damages - GDP variations

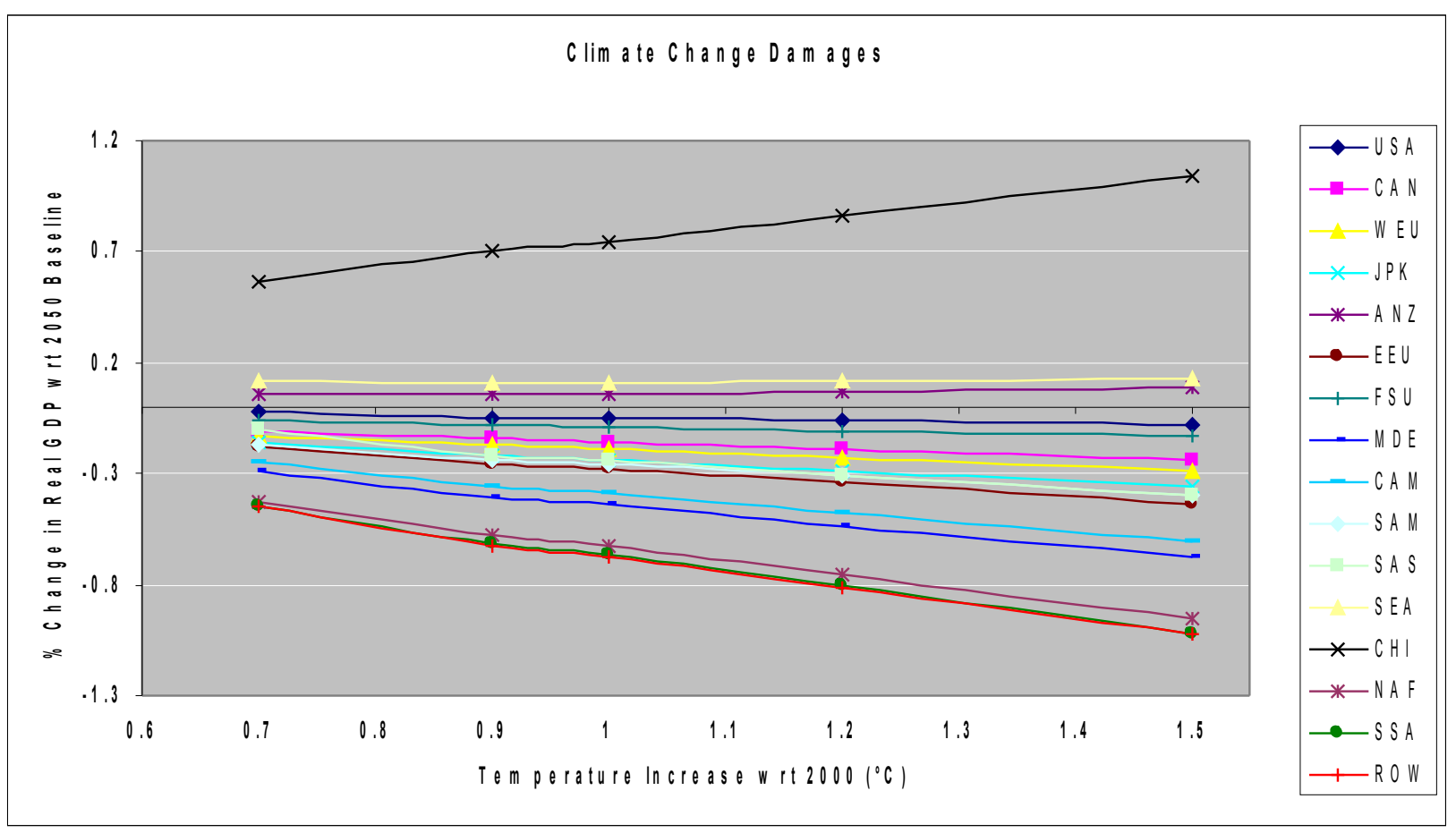

Results shown in Figure 1 can be interpolated by a linear function. Table 1 shows the slope coefficients of these functions, expressing the estimated percentage variation in regional GDP (on average) for $1^{\circ} \mathrm{C}$ increase in temperature.

Table 1: Average variation of regional GDP (\%) for $1^{\circ} \mathrm{C}$ increase in temperature

\begin{tabular}{|l|c|}
\hline \multicolumn{1}{|c|}{ Regions } & $\Delta$ GDP $(\%)$ \\
\hline USA & -0.050 \\
\hline Canada (CAN) & -0.158 \\
\hline Western Europe (WEU) & -0.190 \\
\hline Japan and Korea (JPK) & -0.240 \\
\hline Australia and New Zealand (ANZ) & 0.062 \\
\hline Eastern Europe (EEU) & -0.284 \\
\hline Former Soviet Union (FSU) & -0.090 \\
\hline Middle East (MDE) & -0.446 \\
\hline Central America (CAM) & -0.397 \\
\hline South America (SAM) & -0.260 \\
\hline South Asia (SAS) & -0.246 \\
\hline South East Asia (SEA) & 0.016 \\
\hline China (CHI) & 0.729 \\
\hline North Africa (NAF) & -0.631 \\
\hline Sub-Saharan Africa (SSA) & -0.673 \\
\hline Small Island States (SIS) & -0.680 \\
\hline
\end{tabular}


Results shown in Table 1 suggest that:

- Climate change impacts are negative for nearly all regions, with the exception of Australia-New Zealand, South East Asia, and China. The negative variations range between roughly $-0.7 \%$ of GDP, for Small Island States, to $-0.05 \%$ of GDP for the US.

- Only three regions exhibit gains. However, whereas in Australia-New Zealand and South East Asia these gains are relatively small and not especially sensitive to temperature variations, gains is China are substantial and increasing. The China result is due to a combination of factors. First, there is a significant increase in agricultural productivity, especially for rice. Second, there are notable foreign capital inflows, driven by high expected rate of returns.

- Generally speaking, developing regions perform badly. This is the combined result of (1) stronger primary negative shocks, (2) negative second order effects, like capital outflows (see Table A7: Middle East, Small Island States, Sub-Saharan Africa and Central America) and (3) worsening of the terms of trade (see Table A7: Small Island States, Middle East, North Africa and Central America).

\section{Adopting an alternative CCDF}

To assess the implications of adopting an alternative CCDF, we use the set of temperature-GDP pairs presented in the previous section, to re-calibrate the CCDF employed in the popular RICE 99 integrated assessment model (Nordhaus and Boyer, 1999).

In RICE 99, a distinction is made between potential GDP and actual GDP, net of climate change impacts (NGDP). The two variables are linked by the following function of temperature:

$$
N G D P_{i}(t)=G D P_{i} \frac{1}{1+\theta_{1, i} T+\theta_{2, i} T^{2}}
$$

where $T$ is the world average temperature increase above preindustrial level and $\theta_{1}$ and $\theta_{2}$ are region specific coefficients.

We estimate the values of $\theta_{1}$ and $\theta_{2}$ parameters, using two levels of temperature increase: 0.7 and $1.5^{\circ} \mathrm{C}$, respect to year 2000 . Our findings are summarized in Table 2 below, alongside the original RICE 99 parameter values. 
Figure 2 displays, for all regions, three functions: two non-linear CCDFs (original RICE 99 [R99] and the recalibrated function [R99n]), and one linear CCDF [L], corresponding to the linear interpolation presented in the previous section.

To understand what lies behind the observed differences in CCDFs, it is important to stress that: - our damage coefficients are based on a set of comparative static exercises, referred to the year 2050. Consequently: (a) losses and gains are in 2050 are more significant than in previous years, but less significant than in later years; (b) no transition dynamics is considered, but only instantaneous adjustments from a base case; (c) other dynamic issues, like discounting, are not considered here. - climate-induced catastrophic events, and impacts on human settlements and ecosystems, are not taken into account in our estimation, but they are considered in the RICE 99 damage function, which also includes an evaluation of non-market amenity impacts.

- we do consider changes in tourism flows, not considered in RICE 99.

Most importantly, socio-economic autonomous adaptation, that is, agents' reactions to changes in relative prices, are explicitly considered by our study and not in the Nordhaus and Boyer model. In RICE 99, impacts are assessed one by one, in partial equilibrium settings, and then "summed up". 
Table 2: Damage coefficients

\begin{tabular}{|l|r|r|r|c|}
\hline & \multicolumn{2}{|c|}{ RICE 99 $\left.{ }^{*}\right)$} & \multicolumn{2}{c|}{ Our Estimates } \\
\hline & \multicolumn{1}{|c|}{ THETA1 } & \multicolumn{1}{c|}{ THETA2 } & \multicolumn{1}{c|}{ THETA1 } & \multicolumn{1}{c|}{ THETA2 } \\
\hline USA & -0.0042 & 0.0025 & -0.000092 & 0.000247 \\
\hline JAPAN & -0.0026 & 0.0017 & 0.000547 & 0.000549 \\
\hline EUROPE & -0.001 & 0.0049 & 0.000546 & 0.000504 \\
\hline $\begin{array}{l}\text { Other High } \\
\text { Income (OHI) }\end{array}$ & -0.0108 & 0.0037 & 0.000387 & 0.000120 \\
\hline $\begin{array}{l}\text { High Income } \\
\text { OPEC (HIO) }\end{array}$ & 0.0041 & 0.0015 & -0.000454 & 0.001558 \\
\hline $\begin{array}{l}\text { Middle Income } \\
\text { (MI) }\end{array}$ & 0.0039 & 0.0013 & na & na \\
\hline RUSSIA & -0.0108 & 0.0033 & 0.000229 & 0.000162 \\
\hline $\begin{array}{l}\text { Low-Middle } \\
\text { Income (LMI) }\end{array}$ & 0.0022 & 0.0026 & 0.000969 & 0.001202 \\
\hline $\begin{array}{l}\text { Eastern Europe } \\
\text { (EE) }\end{array}$ & -0.0052 & 0.0019 & 0.000600 & 0.000829 \\
\hline Low Income (LI) & 0.0063 & 0.0025 & na & na \\
\hline CHINA & -0.0041 & 0.002 & -0.003946 & -0.000583 \\
\hline INDIA & 0.0074 & 0.0049 & -0.000265 & 0.000874 \\
\hline AFRICA & 0.0157 & 0.001 & 0.001628 & 0.001734 \\
\hline
\end{tabular}

Notes:

(*) As reported in Nordhaus webpage available at:

http://www.econ.yale.edu/ nordhaus/homepage/Riceprog.html

In Italics those regions are reported which do not coincide perfectly between

the two models, but which are reasonably comparable

na: available

Figure 2: Three alternative regional CCDFs 

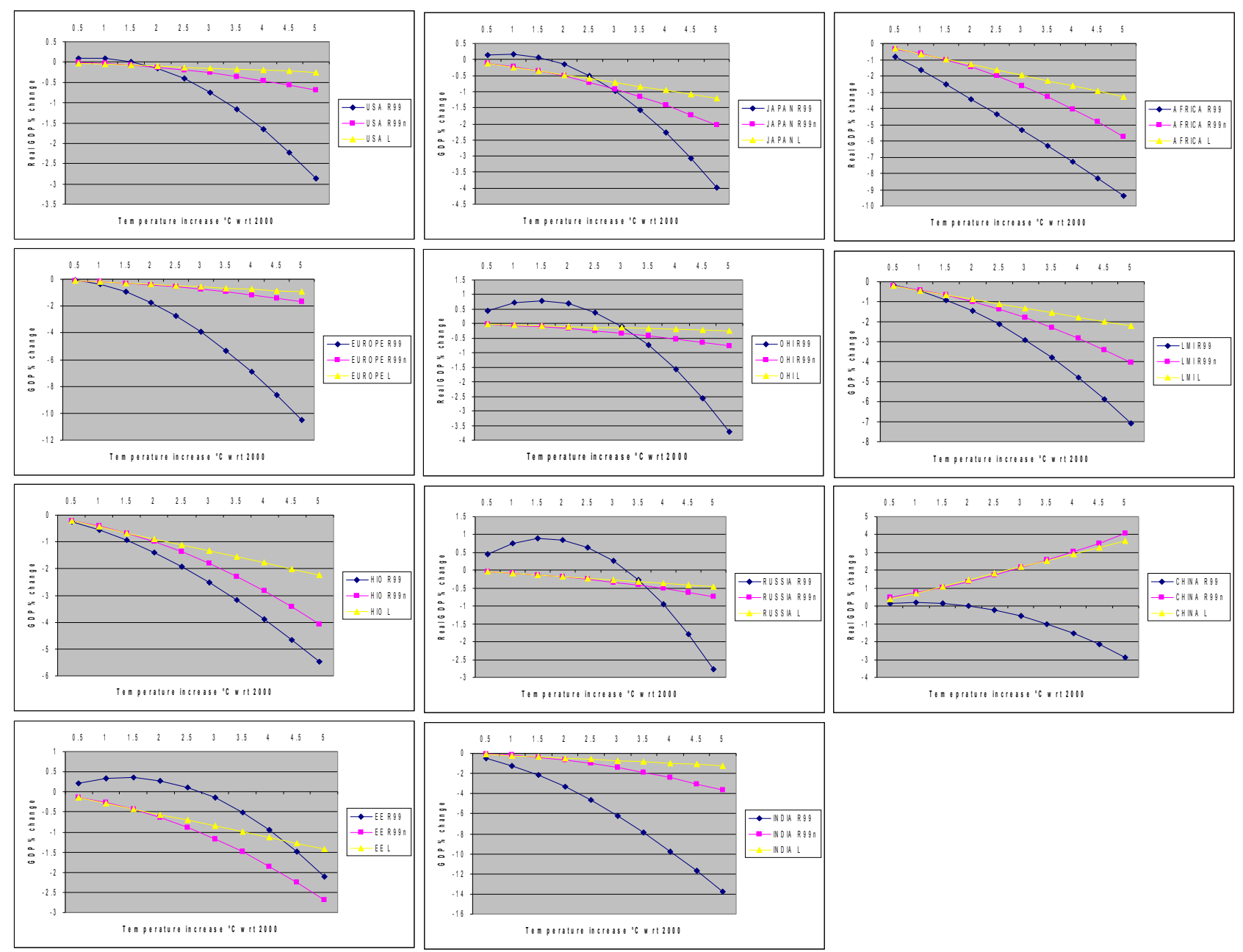

In our case, all impacts are considered simultaneously and consistently, analysing changes in relative competitiveness, trade and capital flows, and consumption patterns.

What all this implies in terms of model results? To illustrate this point, we run the RICE model with old (original) and new (re-estimated) parameter values.

RICE produces a baseline, "business ad usual", scenario, without mitigation policy, and counterfactual scenarios, in which investments and emissions abatement are optimized at the regional level, in a Ramsey-type model. Figure 3 present the time evolution of the regional climate change damage, expressed as percentage losses in GDP, in the baseline and with the two parameter sets.

Estimated damages with new parameters are generally lower than those of the original RICE 99 model, especially in the long term. Moreover, climate change generates long lasting benefits for China, while these are initially smaller and negative after 2095 in the original formulation. On the other hand, we do not see short and mid-term benefits for climate change, except for China.

Figure 3: Comparing parametrisation, climate change damages (\% of GDP) 

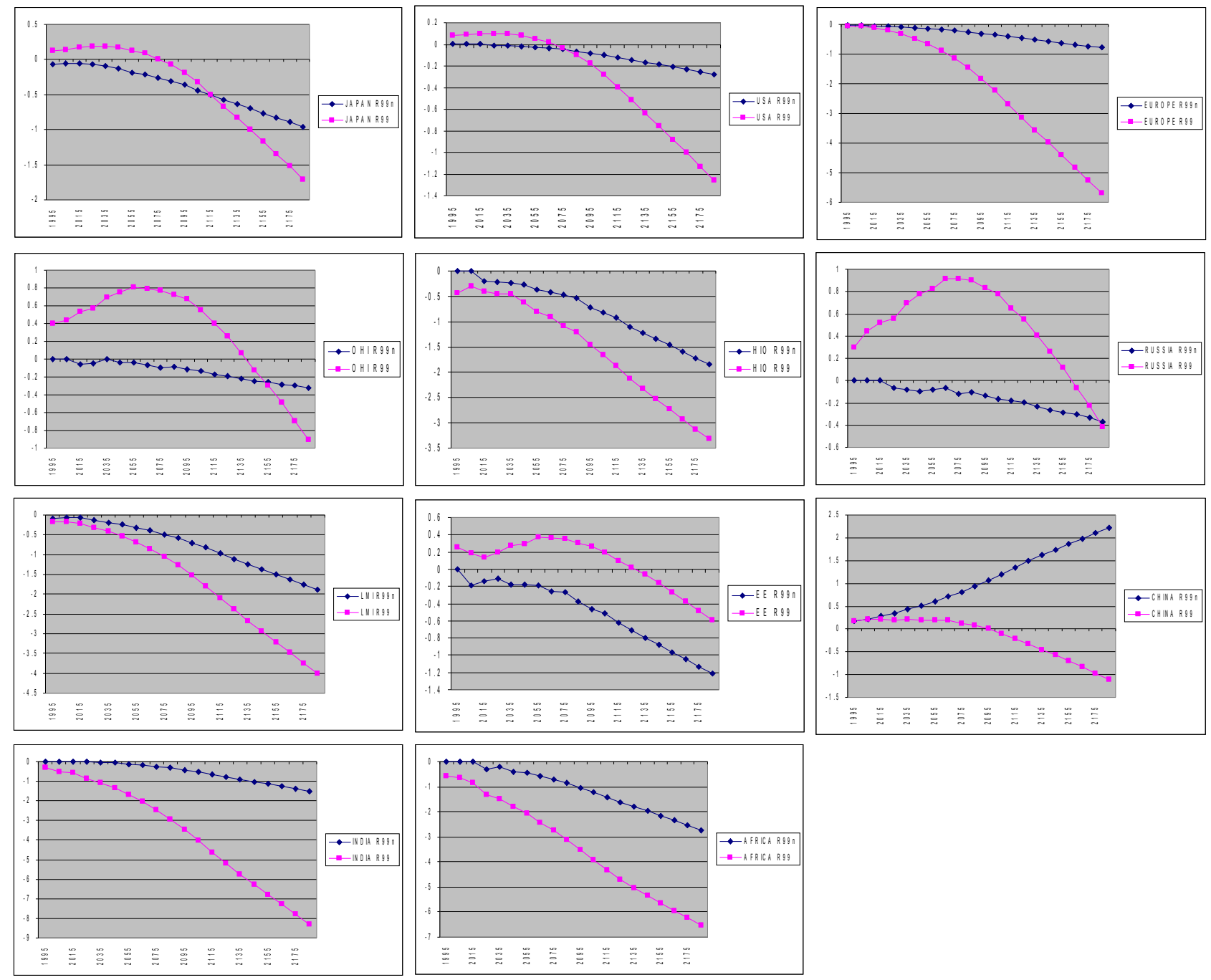

Figure 4 displays total $\mathrm{CO}_{2}$ emissions, estimated by the model in the baseline and in the two counterfactual optimized scenarios, using the two alternative parameter sets. Since the new parameters imply lower aggregated damages, optimal emissions are higher. Up to the year 2075, the optimal emission path with new parameters is actually closer to the $\mathrm{BaU}$ path, in which there is no abatement of $\mathrm{CO}_{2}$ emissions, than to the old optimized path. 
Figure 4: Comparing parametrisation, optimal emission paths

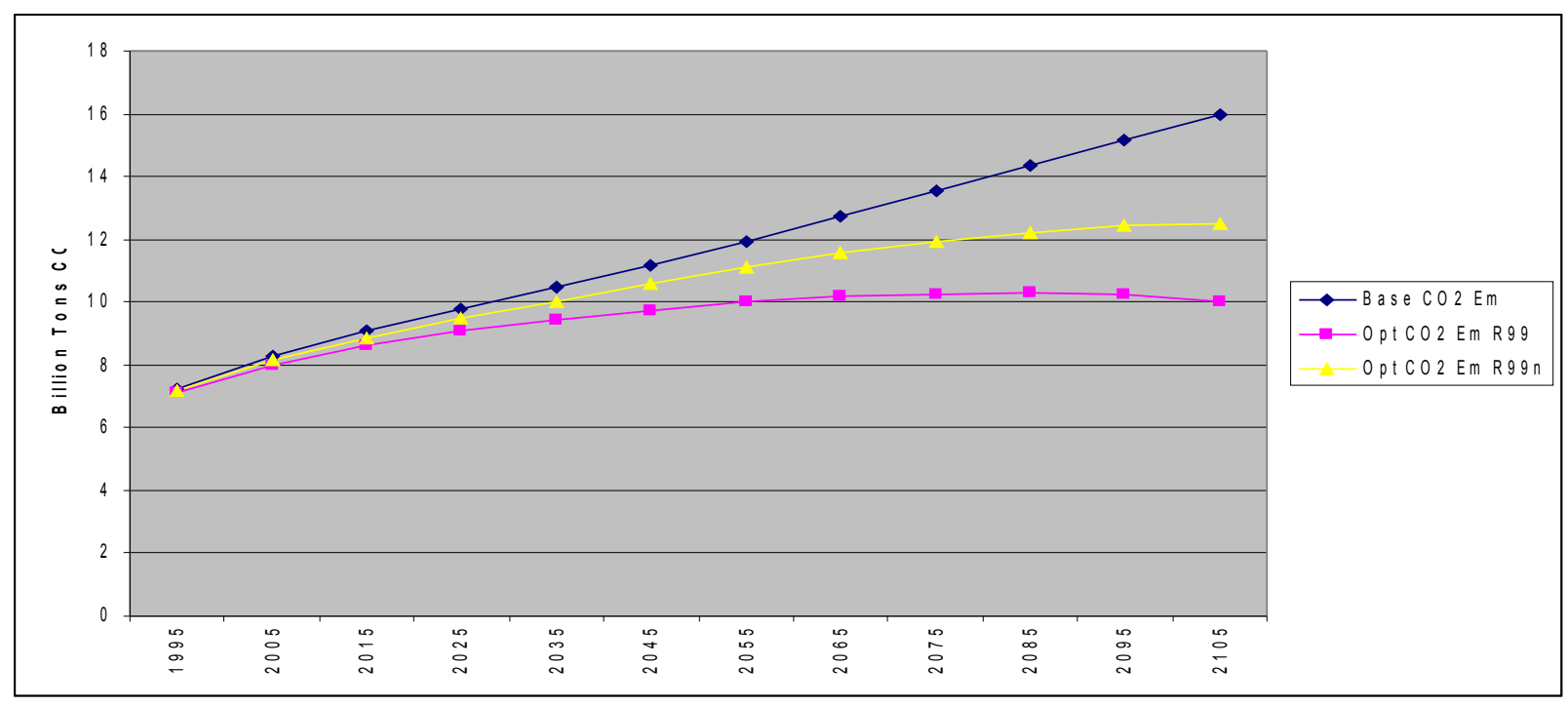

\section{Concluding remarks}

In this paper, we have presented a new methodology for the estimation of climate change damage functions, based on simulations with a CGE model. This methodology is superior to conventional estimation techniques, in terms of consistency, reliability, and theoretical foundations.

In our estimates, economic damages of climate change turn out to be much smaller than in earlier studies, and in a few cases they are, actually, net benefits. This does not rule out the possibility that effects may be dramatic for specific industries or regions (e.g., small island states). It simply means that macroeconomic effects are likely to be smaller than previously expected, because of the intrinsic capability of the economic system to adjust, in response to negative shocks. The general equilibrium model highlights that most of the climate change impacts create distributional issues, which can hardly be appreciated by looking only at broad macroeconomic aggregates, like GDP. This is because expenditure by some individuals becomes income for other individuals in the system, and because even globally negative shocks may generate changes in the relative competitiveness and in the terms of trade.

Results could be improved by adding more impact simulations in the CGE model, e.g,, by addressing issues like future water availability, as well as by enhancing existing impact studies. We do not think, however, that these potential improvements could fundamentally alter the qualitative picture emerged in this work. 


\section{References}

Berrittella, M., Bigano, A., Roson, R. and R.S.J. Tol, (2006) "A general equilibrium analysis of climate change impacts on tourism”, Tourism Management, 25(5), 913-924.

Beniston, M., Diaz, H. F., and Bradley, R. S. (1997), "Climatic Change at High Elevation Sites: An Overview", Climatic Change, 36, 233-251.

Beniston, M., Tol, R. S. J., Delecolle, R., Hoermann, G., Iglesias, A., Innes, J., McMicheal, A. J., Martens, W. J. M., Nemesova, I., Nicholls, R. J., \& Toth, F. L. (1998), "Europe," in The Regional Impacts of Climate Change -- An Assessment of Vulnerability, A Special Report of IPCC Working Group II, R. T. Watson, M. C. Zinyowera, \& R. H. Moss, eds. (eds.), Cambridge University Press, Cambridge, pp. 149-185.

Bigano, A., J.M. Hamilton and R.S.J. Tol (2005), The Impact of Climate Change on Domestic and International Tourism: A Simulation Study, Research unit Sustainability and Global Change FNU58, Hamburg University and Centre for Marine and Atmospheric Science, Hamburg.

Bigano, A., Bosello, F. and G. Marano, (2006), "Energy demand and temperature: a dynamic panel analysis", FEEM Note di Lavoro n. 112.06

Bijlsma, L., Ehler, C. N., Klein, R. J. T., Kulshrestha, S. M., McLean, R. F., Mimura, N., Nicholls, R. J., Nurse, L. A., Perez Nieto, H., Stakhiv, E. Z., Turner, R. K., \& Warrick, R. A. (1996), "Coastal Zones and Small Islands," in Climate Change 1995: Impacts, Adaptations and Mitigation of Climate Change: Scientific-Technical Analyses -- Contribution of Working Group II to the Second Assessment Report of the Intergovernmental Panel on Climate Change, 1 edn, R. T. Watson, M. C. Zinyowera, \& R. H. Moss, eds. (eds.), Cambridge University Press, Cambridge, pp. 289-324.

Bosello, F., Roson, R. and R.S.J. Tol (2006), “ Economy wide estimates of the implications of climate change: human health" Ecological Economics, 58, 579-591.

Bosello, F., Roson, R. and R.S.J. Tol (2007), "Economy wide estimates of the implications of climate change: sea level rise", Environmental and Resource Economics, forthcoming.

Bosello, F. and J. Zhang (2006), "Gli effetti del cambiamento climatico in agricoltura", Questione Agraria, 1-2006, 97-124.

Burniaux J-M., Truong, T.P., (2002) GTAP-E: An Energy-Environmental Version of the GTAP Model, GTAP Technical Paper n.16 (www.gtap.org).

Darwin, R.F. and R.S.J. Tol (2001), "Estimates of the economic effects of sea level rise", Environmental and Resource Economics, 19 (2), 113-129.

Dixon, P. and Rimmer, M., (2002) Dynamic General Equilibrium Modeling for Forecasting and Policy, North Holland.

Hertel, T.W., (1996) Global Trade Analysis: Modeling and applications, Cambridge University Press.

Hertel, T.W., Tsigas, M. (2002), GTAP Data Base Documentation, Chapter 18.c "Primary Factors Shares" (www.gtap.org).

Manne A., (1999) "The Kyoto Protocol: A Cost-Effective Strategy for Meeting Environmental Objectives?", The Energy Journal, special issue, May 1999, pp.1-23.

Manne, A., and R.G. Richels (1992) Buying Greenhouse Insurance: The Economic Costs of CO2 Emission Limits. Cambridge, Mass.: MIT Press. 
Manne, A., Mendelsohn, R. and R.G. Richels (1995), "MERGE: A Model for Evaluating Regional and Global Effects of GHG Reduction Policies." Energy Policy, vol. 23, no. 1, pp. 17-34, .

Manne A. and R. Richels, (2004a), "A Multi-Gas Approach to Climate Policy”, in C.B. Field and M.R. Raupach (eds.), The Global Carbon Cycle, Island Press, Washington, D.C. .

Manne, A. and R. Richels, (2004b), "MERGE an Integrated Assessment Model for Global Climate Change", on line documentation on the MERGE model, available at: http://www.stanford.edu/group/MERGE/GERAD1.pdf

McKibbin, W.J, Wilcoxen, P.J., (1998) The Theoretical and Empirical Structure of the GCubed Model, Economic Modelling, vol. 16(1), 123-48.

Nicholls, R. J. \& Leatherman, S. P. (1995), "Global Sea-level Rise," in When Climate Changes: Potential Impact and Implications, K. M. Strzepek \& J. B. Smith, eds. (eds.), Cambridge University Press, Cambridge.

Nicholls, R. J., Leatherman, S. P., Dennis, K. C., and Volonte, C. R. (1995), "Impacts and Responses to Sea-Level Rise: Qualitative and Quantitative Assessments", Journal of Coastal Research, 14, 26-43.

Nordhaus, W.D. and J. Boyer (1999a), "Roll the Dice again: Economic Models of Global Warming”, MIT Press.

Nordhaus, W.D. and J. Boyer (1999b), "Requiem for Kyoto: An Assessment of the Economics of the Kyoto Protocol," with Joseph G. Boyer, The Energy Journal, Special Issue, 93-130.

Nordhaus, W.D. and D. Popp (1997), "What is the Value of Scientific Knowledge? An Application to Global Warming Using the PRICE Model", The Energy Journal, vol. 18, No. 1, pp. 1-45.

Nordhaus, W.D. and Z. Yang (1996), “A Regional Dynamic General-Equilibrium Model of Alternative Climate Change Strategies", American Economic Review, 4, 741-765.

Pearce, D.W., Cline, W.R., Achanta, A.N., Fankhauser, S., Pachauri, P.K., Tol, R.S.J. And P. Vellinga (1996), "The Social Cost of Climate Change: Greenhouse Damage and Benefits of Control", in Climate Change 1995, Economic and Social Dimensions of Climate Change, Contribution of Working Group III to the Second Assessment Report of the IPCC, Cambridge University Press, UK.

Peck, S. and T. Teisberg (1994), "Optimal carbon emissions trajectories when damages depend on the rate of level of global warming", Climatic Change 28(3), 289-314.

Peck, S. and T. Teisberg (1992), "CETA a model for carbon emission trajectory assessment", Energy Journal, 13(1), 55-78.

Peck, S. and T. Teisberg (1993), "Optimal CO2 Emissions Control with Partial and Full Worldwide Cooperation: An Analysis Using CETA" Palo Alto, Calif.: Electric Power Research Institute

Schneider, S. and J. Sarukan (2001), "Overview of Impacts, Adaptation, and Vulnerability", in Climate Change 2001, Impacts, Adaptation and Vulnerability, Contribution of Working Group II to the Third Assessment Report of the IPCC, Cambridge University Press, UK.

Tol, R.S.J.(2002a), "New estimates of the damage cost of climate change, Part I: Benchmark Estimates", Environmental and Resource Economics, 21(1), 47-73.

Tol, R.S.J. (2002b), "New estimates of the damage cost of climate change, Part II: Dynamic Estimates", Environmental and Resource Economics, 21(2), 135-160. 
Tol, R.S.J. (1996), "The Climate Framework for Uncertainty Negotiation and Distribution" Technical description Version 1.5, IVM .

Tol, R.S.J. (1997), 'On the Optimal Control of Carbon Dioxide Emissions -- An Application of FUND’, Environmental Modelling and Assessment, 2, 151-163.

Tol, R.S.J. (1999), 'Spatial and Temporal Efficiency in Climate Policy: Applications of FUND', Environmental and Resource Economics, 14 (1), 33-49.

Tol, R.S.J. (2005), 'An Emission Intensity Protocol for Climate Change: An Application of FUND', Climate Policy, 4, 269-287. 


\section{Appendix}

Table A1: 2050 - land loss in \% of total macro-regional land

\begin{tabular}{|c|c|c|c|c|c|}
\hline $\begin{array}{c}\mathrm{T} \text { increase } \\
\text { in }{ }^{\circ} \mathrm{C} \text { wrt } \\
2000\end{array}$ & 0.7 & 0.93 & 1 & 1.2 & 1.5 \\
\hline SLR (cm.) & 5 & 8.19 & 9.16 & 11.94 & 16.11 \\
\hline USA & 0.011 & 0.018 & 0.020 & 0.026 & 0.035 \\
\hline CAN & 0.001 & 0.001 & 0.001 & 0.001 & 0.002 \\
\hline WEU & 0.006 & 0.010 & 0.011 & 0.014 & 0.019 \\
\hline JPK & 0.028 & 0.047 & 0.052 & 0.068 & 0.092 \\
\hline ANZ & 0.002 & 0.003 & 0.004 & 0.005 & 0.006 \\
\hline EEU & 0.008 & 0.013 & 0.015 & 0.020 & 0.027 \\
\hline FSU & 0.003 & 0.005 & 0.005 & 0.007 & 0.010 \\
\hline MDE & 0.001 & 0.002 & 0.003 & 0.004 & 0.005 \\
\hline CAM & 0.025 & 0.040 & 0.045 & 0.059 & 0.079 \\
\hline SAM & 0.008 & 0.014 & 0.015 & 0.020 & 0.027 \\
\hline SAS & 0.085 & 0.139 & 0.156 & 0.203 & 0.274 \\
\hline SEA & 0.173 & 0.283 & 0.317 & 0.413 & 0.557 \\
\hline CHIN & 0.019 & 0.031 & 0.034 & 0.045 & 0.060 \\
\hline NAF & 0.008 & 0.013 & 0.014 & 0.019 & 0.025 \\
\hline SSA & 0.027 & 0.044 & 0.049 & 0.064 & 0.086 \\
\hline SIS & 0.034 & 0.056 & 0.062 & 0.081 & 0.110 \\
\hline
\end{tabular}


Table A2: Changes in market service demand and income flows implied by changes in tourism demand.

\begin{tabular}{|c|c|c|c|c|c|c|c|c|c|c|}
\hline \multirow{2}{*}{\begin{tabular}{|c|}
$\mathrm{T}$ \\
increase \\
in ${ }^{\circ} \mathrm{C}$ wrt \\
2000 \\
\end{tabular}} & \multicolumn{2}{|c|}{0.7} & \multicolumn{2}{|c|}{0.93} & \multicolumn{2}{|c|}{1} & \multicolumn{2}{|c|}{1.2} & \multicolumn{2}{|c|}{1.5} \\
\hline & $\begin{array}{c}\% \text { Ch. } \\
\text { in } \\
\text { Mserv } \\
\text { Dem. }\end{array}$ & $\begin{array}{c}\text { Income } \\
\text { trnsfs } \\
(\mathrm{BI} \$)\end{array}$ & $\begin{array}{c}\% \text { Ch. } \\
\text { in } \\
\text { Mserv } \\
\text { Dem. }\end{array}$ & $\begin{array}{c}\text { Income } \\
\text { trnsfs } \\
(\mathrm{BI} \$)\end{array}$ & $\begin{array}{l}\% \text { Ch. } \\
\text { in } \\
\text { Mserv } \\
\text { Dem. }\end{array}$ & $\begin{array}{l}\text { Income } \\
\text { trnsfs } \\
(\mathrm{BI} \$)\end{array}$ & $\left|\begin{array}{c}\% \text { Ch. in } \\
\text { Mserv } \\
\text { Dem. }\end{array}\right|$ & $\begin{array}{c}\text { Income } \\
\text { trnsfs } \\
(\mathrm{BI} \$)\end{array}$ & $\begin{array}{l}\% \text { Ch. } \\
\text { in } \\
\text { Mserv } \\
\text { Dem. }\end{array}$ & $\begin{array}{c}\text { Income } \\
\text { trnsfs } \\
\text { (BI \$) }\end{array}$ \\
\hline USA & -0.65 & -64.7 & -0.87 & -86.0 & -0.93 & -92.5 & -1.12 & -110.9 & -1.40 & -138.7 \\
\hline CAN & 0.38 & 3.2 & 0.51 & 4.2 & 0.54 & 4.5 & 0.65 & 5.4 & 0.82 & 6.8 \\
\hline WEU & 0.71 & 78.1 & 0.94 & 103.8 & 1.01 & 111.6 & 1.21 & 133.9 & 1.52 & 167.3 \\
\hline JPK & 4.15 & 246.4 & 5.52 & 327.3 & 5.93 & \begin{tabular}{|l|l}
352.0 \\
\end{tabular} & 7.12 & 422.3 & 8.90 & 527.9 \\
\hline ANZ & -1.14 & -6.5 & -1.51 & $\begin{array}{l}-8.7 \\
\end{array}$ & -1.63 & \begin{tabular}{|l|l}
-9.3 \\
\end{tabular} & -1.95 & -11.2 & -2.44 & -14.0 \\
\hline EEU & -2.35 & -8.8 & \begin{tabular}{|l|}
-3.12 \\
\end{tabular} & -11.7 & -3.36 & -12.6 & -4.03 & -15.1 & -5.04 & -18.9 \\
\hline FSU & 0.00 & 0.0 & 0.00 & 0.0 & 0.00 & 0.0 & 0.00 & 0.0 & 0.00 & 0.0 \\
\hline MDE & -4.48 & -41.8 & -5.95 & -55.5 & -6.40 & -59.7 & -7.68 & -71.6 & -9.60 & -89.6 \\
\hline CAM & -4.16 & -30.7 & -5.53 & -40.8 & -5.94 & -43.9 & -7.13 & -52.6 & -8.91 & -65.8 \\
\hline SAM & -1.14 & -26.2 & -1.51 & -34.8 & -1.63 & -37.4 & -1.95 & -44.9 & -2.44 & -56.1 \\
\hline SAS & -1.15 & -6.5 & -1.53 & -8.7 & -1.64 & -9.3 & -1.97 & -11.2 & -2.47 & -14.0 \\
\hline SEA & -4.07 & -41.3 & -5.41 & -54.9 & -5.82 & -59.1 & -6.98 & -70.9 & -8.73 & -88.6 \\
\hline $\mathrm{CHI}$ & -5.30 & -30.8 & -7.04 & -40.9 & -7.57 & -44.0 & -9.09 & -52.8 & -11.36 & -66.0 \\
\hline NAF & -2.42 & -4.1 & -3.22 & -5.4 & -3.46 & -5.8 & -4.15 & -7.0 & -5.19 & -8.7 \\
\hline SSA & -2.30 & -13.6 & -3.06 & -18.1 & -3.29 & -19.4 & -3.94 & -23.3 & -4.93 & -29.2 \\
\hline SIS & -9.23 & -52.5 & -12.26 & -69.8 & -13.19 & -75.1 & -15.83 & -90.1 & -19.78 & -112.6 \\
\hline
\end{tabular}

Table A3: Changes in energy demand

\begin{tabular}{|c|c|c|c|c|c|c|c|c|c|c|c|c|}
\hline \multirow{2}{*}{\begin{tabular}{|c|}
$\mathrm{T}$ \\
increase \\
in ${ }^{\circ} \mathrm{C}$ wrt \\
2000 \\
\end{tabular}} & \multicolumn{4}{|c|}{0.7} & \multicolumn{4}{|c|}{0.93} & \multicolumn{4}{|c|}{1} \\
\hline & Coal & $\begin{array}{l}\text { Nat } \\
\text { Gas }\end{array}$ & Oil_Prodcts & Electricity & Coal & $\begin{array}{l}\text { Nat } \\
\text { Gas }\end{array}$ & Oil_Prodcts & Electricity & Coal & \begin{tabular}{l|} 
Nat \\
Gas
\end{tabular} & Oil_Prodcts & Electricity \\
\hline USA & 11.36 & \begin{tabular}{|l|}
-7.28 \\
\end{tabular} & -12.20 & -2.30 & 15.16 & -9.72 & -16.28 & -3.07 & 16.23 & -10.40 & -17.43 & -3.29 \\
\hline CAN & 26.05 & -16.69 & -27.97 & -5.27 & 34.76 & -22.27 & -37.33 & -7.04 & 37.21 & $\mid$ & -39.96 & \begin{tabular}{|c|}
-7.53 \\
\end{tabular} \\
\hline WEU & 11.27 & -7.22 & -12.11 & -2.28 & 15.04 & -9.64 & -16.16 & -3.05 & 16.10 & $\mid-10.32$ & -17.29 & -3.26 \\
\hline JPK & 10.00 & -6.41 & -10.74 & -2.02 & 13.35 & -8.55 & -14.33 & -2.70 & 14.29 & \begin{tabular}{|l|}
-9.16 \\
\end{tabular} & -15.34 & -2.89 \\
\hline ANZ & 5.10 & -3.27 & -5.48 & -1.03 & 6.81 & -4.36 & -7.31 & -1.38 & 7.29 & -4.67 & -7.83 & -1.48 \\
\hline EEU & 10.48 & -6.71 & -11.25 & -2.12 & 13.98 & -8.96 & -15.01 & -2.83 & 14.97 & \begin{tabular}{|l|}
-9.59 \\
\end{tabular} & -16.07 & -3.03 \\
\hline FSU & 23.00 & $\mid-14.74$ & -24.70 & -4.66 & 30.69 & -19.67 & -32.96 & -6.21 & 32.85 & -21.05 & -35.28 & -6.65 \\
\hline MDE & 7.25 & \begin{tabular}{|l|}
-4.64 \\
\end{tabular} & -7.78 & -1.47 & 9.67 & -6.20 & -10.38 & -1.96 & 10.35 & \begin{tabular}{|l|}
-6.63 \\
\end{tabular} & -11.11 & -2.10 \\
\hline CAM & 5.27 & -3.38 & -5.66 & $\mid-1.07$ & 7.03 & -4.50 & -7.55 & -1.42 & 7.53 & -4.82 & -8.08 & -1.52 \\
\hline LAM & 5.24 & -3.36 & -5.63 & -1.06 & 7.00 & -4.48 & -7.51 & -1.42 & 7.49 & -4.80 & -8.04 & -1.52 \\
\hline SAS & 5.88 & -3.77 & -6.32 & -1.19 & 7.85 & -5.03 & -8.43 & -1.59 & 8.40 & -5.38 & -9.02 & -1.70 \\
\hline SEA & 4.06 & -2.60 & -4.36 & -0.82 & 5.42 & -3.47 & -5.82 & -1.10 & 5.80 & -3.71 & -6.23 & -1.17 \\
\hline $\mathrm{CHI}$ & 11.31 & -7.25 & -12.15 & -2.29 & 15.10 & -9.68 & -16.21 & -3.06 & 16.16 & $\mid-10.36$ & -17.36 & -3.27 \\
\hline MAF & 6.61 & -4.24 & -7.10 & -1.34 & 8.82 & -5.65 & -9.47 & -1.79 & 9.45 & \begin{tabular}{|l|}
-6.05 \\
\end{tabular} & -10.14 & -1.91 \\
\hline SSA & 5.04 & -3.23 & -5.41 & -1.02 & 6.73 & -4.31 & -7.22 & -1.36 & 7.20 & -4.61 & -7.73 & -1.46 \\
\hline SIS & 6.38 & \begin{tabular}{|l|}
-4.09 \\
\end{tabular} & -6.85 & -1.29 & 8.52 & \begin{tabular}{|c|}
-5.46 \\
\end{tabular} & -9.14 & -1.72 & 9.12 & \begin{tabular}{|l|}
-5.84 \\
\end{tabular} & -9.79 & -1.85 \\
\hline
\end{tabular}




\begin{tabular}{|c|c|c|c|c|c|c|c|c|}
\hline \multirow{2}{*}{$\begin{array}{c}\text { T increase } \\
\text { in }{ }^{\circ} \mathrm{C} \text { wrt } \\
2000\end{array}$} & \multicolumn{4}{|c|}{1.2} & \multicolumn{4}{|c|}{1.5} \\
\hline & Coal & Nat Gas & Oil_Prodcts & Electricity & Coal & Nat Gas & Oil_Prodcts & Electricity \\
\hline USA & 19.48 & \begin{tabular}{|l|}
-12.48 \\
\end{tabular} & -20.91 & -3.94 & 24.35 & -15.60 & -26.14 & -4.93 \\
\hline CAN & 44.65 & -28.61 & -47.95 & -9.04 & 55.82 & -35.77 & -59.94 & -11.30 \\
\hline WEU & 19.33 & -12.38 & -20.75 & -3.91 & \begin{tabular}{|l|}
24.16 \\
\end{tabular} & -15.48 & -25.94 & -4.89 \\
\hline JPK & 17.15 & -10.99 & -18.41 & -3.47 & 21.43 & -13.73 & -23.01 & -4.34 \\
\hline ANZ & 8.75 & -5.60 & -9.39 & -1.77 & 10.93 & -7.01 & -11.74 & -2.21 \\
\hline EEU & 17.96 & -11.51 & -19.29 & -3.64 & 22.45 & -14.39 & -24.11 & -4.55 \\
\hline FSU & 39.43 & -25.26 & -42.34 & -7.98 & 49.28 & -31.58 & -52.92 & -9.98 \\
\hline MDE & 12.42 & -7.96 & -13.34 & -2.51 & \begin{tabular}{|l|}
15.53 \\
\end{tabular} & -9.95 & -16.67 & -3.14 \\
\hline CAM & 9.03 & -5.79 & -9.70 & -1.83 & 11.29 & -7.23 & -12.12 & -2.29 \\
\hline LAM & 8.99 & -5.76 & -9.65 & -1.82 & 11.24 & -7.20 & -12.07 & -2.27 \\
\hline SAS & 10.08 & -6.46 & -10.83 & -2.04 & 12.61 & -8.08 & -13.54 & -2.55 \\
\hline SEA & 6.96 & -4.46 & -7.47 & -1.41 & \begin{tabular}{|l|}
8.70 \\
\end{tabular} & -5.57 & -9.34 & -1.76 \\
\hline $\mathrm{CHI}$ & 19.40 & -12.43 & -20.83 & -3.93 & 24.25 & -15.54 & -26.03 & -4.91 \\
\hline MAF & 11.33 & -7.26 & -12.17 & -2.29 & \begin{tabular}{|l|}
14.17 \\
\end{tabular} & -9.08 & -15.21 & -2.87 \\
\hline SSA & 8.64 & -5.54 & -9.28 & -1.75 & 10.80 & -6.92 & -11.60 & -2.19 \\
\hline SIS & 10.94 & -7.01 & -11.75 & -2.21 & \begin{tabular}{|c|}
13.67 \\
\end{tabular} & -8.76 & -14.68 & -2.77 \\
\hline
\end{tabular}


Table A4: Changes in Yields

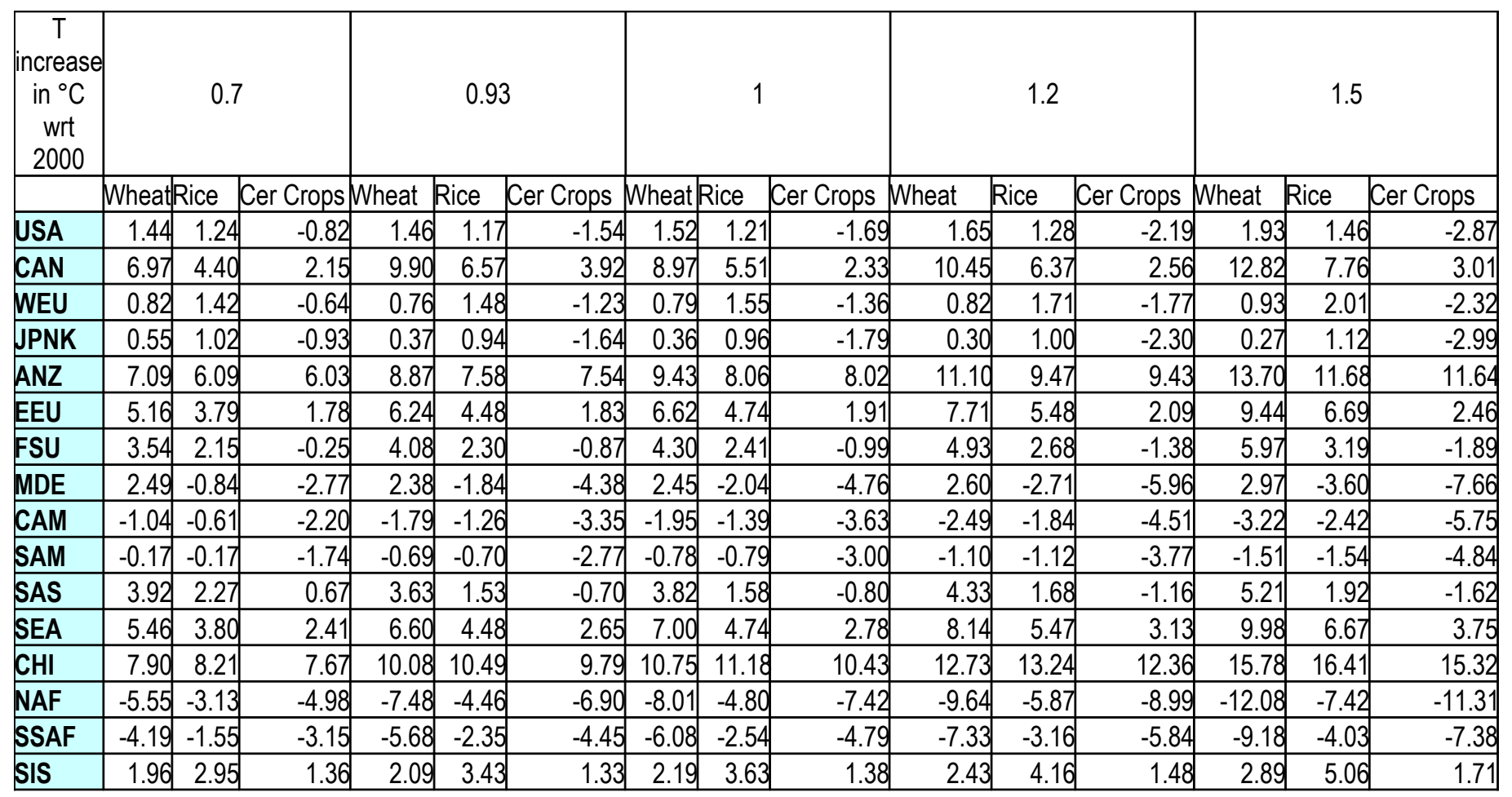

Table A5: changes in labour productivity induced by changes in mortality and morbidity

\begin{tabular}{|c|r|r|r|r|r|}
\hline $\begin{array}{c}\text { T increase } \\
\text { in }{ }^{\circ} \mathrm{C} \text { wrt } \\
2000\end{array}$ & \multicolumn{1}{|c|}{0.7} & \multicolumn{1}{c|}{0.93} & \multicolumn{1}{|c|}{1} & \multicolumn{1}{c|}{1.2} & \multicolumn{1}{c|}{1.5} \\
\hline USA & -0.02 & -0.04 & -0.04 & -0.05 & -0.06 \\
\hline CAN & 0.12 & 0.16 & 0.17 & 0.20 & 0.25 \\
\hline WEU & 0.04 & 0.06 & 0.06 & 0.07 & 0.09 \\
\hline JPK & 0.03 & 0.03 & 0.03 & 0.04 & 0.04 \\
\hline ANZ & -0.02 & -0.03 & -0.04 & -0.05 & -0.06 \\
\hline EEU & 0.04 & 0.06 & 0.06 & 0.07 & 0.09 \\
\hline FSU & 0.05 & 0.07 & 0.07 & 0.09 & 0.11 \\
\hline MDE & -0.13 & -0.18 & -0.19 & -0.23 & -0.29 \\
\hline CAM & -0.08 & -0.12 & -0.13 & -0.16 & -0.20 \\
\hline SAM & -0.07 & -0.10 & -0.11 & -0.13 & -0.17 \\
\hline SAS & -0.09 & -0.12 & -0.13 & -0.16 & -0.20 \\
\hline SEA & -0.08 & -0.12 & -0.13 & -0.15 & -0.20 \\
\hline CHIN & 0.05 & 0.07 & 0.08 & 0.09 & 0.11 \\
\hline NAF & -0.24 & -0.32 & -0.35 & -0.42 & -0.53 \\
\hline SSA & -0.39 & -0.53 & -0.57 & -0.69 & -0.87 \\
\hline SIS & -0.16 & -0.22 & -0.24 & -0.29 & -0.36 \\
\hline
\end{tabular}


Table A6: changes in private and public health care expenditure induced by changes in mortality and morbidity

\begin{tabular}{|c|c|c|c|c|c|c|c|c|c|c|}
\hline $\begin{array}{c}\mathrm{T} \\
\text { increase } \\
\text { in }{ }^{\circ} \mathrm{C} \text { wrt } \\
2000\end{array}$ & 0.7 & 0.93 & 1 & 1.2 & 1.5 & 0.7 & 0.93 & 1 & 1.2 & 1.5 \\
\hline & \multicolumn{5}{|c|}{ Changes in private health care expenditure } & \multicolumn{5}{|c|}{ Changes in public health care expenditure } \\
\hline USA & -0.009 & -0.010 & -0.010 & -0.011 & -0.013 & -0.074 & -0.083 & -0.086 & -0.094 & -0.106 \\
\hline CAN & -0.013 & -0.017 & -0.018 & -0.021 & -0.026 & -0.213 & -0.282 & -0.302 & -0.361 & -0.450 \\
\hline WEU & -0.005 & -0.007 & -0.007 & -0.009 & -0.011 & -0.131 & -0.169 & -0.179 & -0.212 & -0.260 \\
\hline JPK & 0.002 & 0.004 & 0.004 & 0.006 & 0.008 & 0.005 & 0.058 & 0.073 & 0.118 & 0.186 \\
\hline ANZ & 0.010 & 0.014 & 0.015 & 0.019 & 0.024 & 0.182 & 0.260 & 0.282 & 0.349 & 0.449 \\
\hline EEU & -0.002 & -0.003 & -0.003 & -0.004 & -0.004 & -0.084 & -0.110 & -0.117 & -0.139 & -0.172 \\
\hline FSU & -0.006 & -0.008 & -0.008 & -0.010 & -0.012 & -0.117 & -0.154 & -0.164 & -0.196 & -0.242 \\
\hline MDE & 0.027 & 0.037 & 0.040 & 0.048 & 0.057 & 0.410 & 0.562 & 0.609 & 0.723 & 0.836 \\
\hline CAM & 0.017 & 0.024 & 0.026 & \begin{tabular}{l|l}
0.032 \\
\end{tabular} & 0.042 & 0.224 & 0.322 & 0.350 & 0.435 & 0.561 \\
\hline SAM & 0.019 & 0.028 & 0.030 & 0.038 & 0.049 & 0.173 & 0.256 & 0.280 & 0.351 & 0.458 \\
\hline SAS & 0.014 & 0.020 & 0.021 & 0.026 & 0.033 & 0.060 & 0.084 & 0.090 & 0.111 & 0.141 \\
\hline SEA & 0.023 & 0.033 & 0.036 & 0.044 & 0.056 & 0.265 & 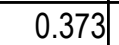 & 0.403 & 0.496 & 0.635 \\
\hline $\mathrm{CHI}$ & 0.003 & 0.004 & 0.004 & 0.005 & 0.007 & 0.032 & \begin{tabular}{|c|c|}
0.047 \\
\end{tabular} & 0.051 & 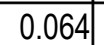 & 0.083 \\
\hline NAF & 0.022 & 0.030 & 0.033 & 0.040 & 0.051 & 0.423 & 0.580 & 0.627 & 0.763 & 0.968 \\
\hline SSA & 0.015 & 0.022 & 0.024 & 0.030 & 0.039 & 0.094 & 0.139 & 0.151 & 0.190 & 0.249 \\
\hline SIS & 0.033 & 0.046 & 0.049 & 0.060 & \begin{tabular}{c|c|}
0.077 \\
\end{tabular} & 0.562 & 0.786 & 0.849 & 1.040 & 1.326 \\
\hline
\end{tabular}

Table A7: Economic implications of $1{ }^{\circ} \mathrm{C}$ increase in temperature.

\begin{tabular}{|c|c|c|c|c|c|c|c|c|c|}
\hline & GDP & $\begin{array}{l}\text { Investment } \\
\text { Flows }\end{array}$ & $\begin{array}{c}\text { Terms of } \\
\text { trade }\end{array}$ & Land Price & Lab Price & CO2 Ems. & $\begin{array}{l}\text { Capital } \\
\text { Returns }\end{array}$ & \multicolumn{2}{|c|}{ World Price Index } \\
\hline USA & -0.023 & -0.14 & -0.44 & 6.28 & -1.12 & -2.9 & -1.24 & Rice & -6.02 \\
\hline CAN & -0.107 & 0.44 & 0.16 & 3.34 & 0.10 & -9.35 & -0.15 & Wheat & -1.03 \\
\hline WEU & -0.127 & 0.93 & 0.37 & 0.38 & 0.43 & -4.56 & 0.69 & CerCrops & 2.84 \\
\hline JPK & -0.161 & 2.09 & 4.15 & -27.72 & 5.52 & -4.41 & 5.73 & VegFruits & 2.33 \\
\hline ANZ & 0.055 & 0.08 & -0.44 & 3.75 & -0.67 & 0.81 & -0.80 & Animals & 1.74 \\
\hline EEU & -0.182 & -1.03 & -0.59 & 6.97 & -1.79 & -0.35 & -1.97 & Forestry & 0.86 \\
\hline FSU & -0.09 & -0.68 & -0.82 & 4.62 & -1 & -3.79 & -1.93 & Fishing & 1.52 \\
\hline MDE & -0.43 & -4.08 & -3.69 & 20.89 & -5.32 & -0.85 & -5.80 & Coal & 1.04 \\
\hline CAM & -0.39 & -2.75 & -1.19 & 12.19 & -4.86 & -0.40 & -4.51 & Oil & -4.54 \\
\hline SAM & -0.25 & -0.67 & -0.17 & 8.19 & -2.51 & -1.71 & -2.52 & Gas & -1.52 \\
\hline SAS & -0.24 & -0.15 & 1.28 & 4.91 & -1.09 & -1.42 & -0.87 & Oil_Pcts & -3.46 \\
\hline SEA & 0.11 & -0.79 & -0.7 & 6.21 & -1.88 & 0.73 & -1.65 & Electricity & -0.28 \\
\hline $\mathrm{CHI}$ & 0.74 & 1.03 & -0.73 & 1.67 & 0.39 & 0.03 & 0.42 & Water & -0.23 \\
\hline NAF & -0.62 & -0.83 & -1.76 & 13.98 & -2.72 & -2.56 & -2.39 & En_Int_Ind & -0.34 \\
\hline SSA & -0.66 & -2.01 & -0.91 & 11.48 & -3.93 & -0.53 & -3.62 & Oth_Ind & 0.06 \\
\hline SIS & -0.67 & -8.69 & -7.69 & 32.79 & -14.34 & 2.40 & -15.56 & MServ & -0.04 \\
\hline & & & & & & & & NMServ & -0.2 \\
\hline
\end{tabular}

All values expressed as \% change wrt the base case (2050 without climate change) 